Received : Mei 2017

\title{
Pengembangan Infrastruktur Air Baku Kota Balikpapan
}

\author{
Mersianty ${ }^{{ }^{*}}$, Mahfud ${ }^{2}$ \\ ${ }^{1,2}$ Politeknik Negeri Balikpapan \\ E-mail : mersianty@poltekba.ac.id
}

\begin{abstract}
The raw water crisis in the city of Balikpapan is still the source of the city's problems until now. The urban water supply of $\pm 689,000$ people is not fully serviced, covering only $82 \%$ of the population. In addition to water deficit problems that tend to increase every year, the decline in water quality due to pollution and leakage rates in the raw water supply system is also still high. Some alternatives to the development of raw water infrastructure that can be selected to overcome the problem of raw water crisis in the city of Balikpapan are (1) by building embungs, dams and other reservoirs with a total of $830 \mathrm{lt} / \mathrm{sec}$, (2) interconnection interconnection between the DASS from Samboja Dam in Kukar District as large as 100 lt / sec and from Sepaku Semoi Dam in North Penajam Paser regency of 1,500 lt / sec so that the total collection that can be supplied to Balikpapan city is 1,600 lt / sec. (3) Innovation of raw water source procurement by recycling process. Decision-making on selected alternatives should go through a feasibility test process that meets the technical and environmental benefit criteria, socio-economic benefits and financial benefits.
\end{abstract}

Keywords: raw water, decision making, feasibility study.

\begin{abstract}
Abstrak
Krisis air baku di kota Balikpapan masih menjadi sumber permasalahan kota sampai saat ini. Kebutuhan air bersih masyarakat kota yang berjumlah \pm 689.000 jiwa belum sepenuhnya terlayani, baru mencakup $82 \%$ dari jumlah penduduk. Selain permasalahan defisit air yang cenderung meningkat setiap tahunnya, penurunan kualitas air akibat pencemaran serta tingkat kebocoran pada sistem suplai air baku juga masih tinggi.Beberapa alternatif pengembangan infrastruktur air baku yang dapat dipilih untuk mengatasi permasalahan krisis air baku di kota Balikpapan yaitu(1) dengan membangun embung, bendungan dan penampungan lainnya dengan total 830 lt/det, (2) pengambilan interkoneksi antar DAS antara lain dari Bendungan Samboja di Kabupaten Kukar sedesar 100 lt/det dan dari Bendungan Sepaku Semoi di Kabupaten Penajam Paser Utara sebesar 1.500 lt/det sehingga total pengambilan yang dapat di suplai ke kota Balikpapan sebesar 1.600 lt/det. (3) Inovasi pengadaan sumber air baku dengan proses daur ulang (Recycling). Pengambilan keputusan terhadap alternatif yang dipilih harus melalui proses uji kelayakan yang memenuhi kriteria manfaat teknis dan lingkungan, manfaat sosial ekonomi dan manfaat finansial.
\end{abstract}

Kata kunci : air baku, pengambilan keputusan, studi kelayakan.

\section{Pendahuluan}

\subsection{Infrastruktur Air Baku Kota Balikpapan.}

Kekurangan air baku telah dialami masyarakat kota Balikpapan sejak tahun 2010 dimana terjadi defisit air baku sebesar 365 1/det yang terus meningkat sampai tahun 2015 defisit air baku mencapai \pm 1135 1/det. Beberapa langkah strategis yang telah di tuangkan dalam Rencana Pembangunan Jangka Menengah Daerah (RPJMD) kota Balikpapan tahun 2011 untuk mengatasi permasalahan kekurangan air baku direncanakan akan dibangun waduk Teritip dan waduk Wain Bugis namun hingga tahun 2014 baru waduk teritip yang telah dimulai tahapan pembebasan lahannya.

Untuk mengatasi kelangkaan air baku masyarakat Balikpapan, saat ini PDAM kota Balikpapan mengupayakan sumur dalam 150 1/det, namun solusi ini merupakan program jangka pendek yang belum dapat menjawab tantangan kebutuhan air baku yang terus meningkat setiap tahunnya. Peran pemerintah daerah dan pusat dalam pengambilan keputusan untuk mengatasi hambatan-hambatan 
dalam pengadaan infrastruktur air baku masih terkesan lambat, hal ini karena kelayakan suatu pengadaan infrastruktur sangat dipengaruhi oleh berbagai aspek yaitu aspek teknis, lingkungan, ekonomi/finansial, sosial dan legal [7].

\subsection{Daerah Wilayah Sungai (DAS) kota Balikpapan}

Secara geografis wilayah Kota Balikpapan berada antara 1,0 LS - 1,5 LS dan 116,5 BT - 117,5 yang luasnya sekitar $50.330,57 \mathrm{Ha}$ atau sekitar 503,3 $\mathrm{Km}^{2}$. Kondisi topografi kota yang berbukitbukit, menyebabkan pola aliran air tanah yang terbentuk mengalir dari arah wilayah bagian utara menuju kearah selatan kota. Yaitu dengan kelerengan 0-2 \% seluas $7.050 \mathrm{Ha}, 2-15 \%$ seluas $3.325 \mathrm{Ha}, 15$ - 40 $\%$ seluas $21.306 \mathrm{Ha}$ dan lebih dari $40 \%$ seluas $18.650 \mathrm{Ha}$.

Sungai-sungai yang terdapat dalam wilayah kota Balikpapan merupakan tipe sungai tadah hujan dengan alur sungai yang pendek dan badan sungai kecil dan sempit. Dalam rencana tata ruang wilayah kota Balikpapan terdapat 32 Daerah Aliran Sungai (DAS) yang terdiri dari sungaisungai besar dan kecil. Sungai-sungai yang cukup besar yaitu Sungai Wain Besar, Sungai Somber dan Sungai Manggar Besar.

Keterbatasan akses penduduk kota akan air bersih berdampak padapemanfaatan air tanah yang cukup tinggi untuk memenuhi kebutuhan air bersih. Pengambilan air tanah yang berlebihan tentunya akan berdampak pada penurunan muka air tanah, salinasi dan instrusi air laut. Kasus instrusi air laut dan salinasi telah terjadi diwilayah Sungai Wain, Sungai Somber, Sungai Manggar, Sungai Tempadung dan sungai Lempasuang [2].

Ketersediaan debit air sungai sangat tergantung pada curah hujan, besarnya curah hujan rata-rata kota Balikpapan adalah $150 \mathrm{~mm} /$ tahun. Sungai-sungai kota Balikpapan juga sekaligus menjadi sistem drainase primer kota, hal ini berdampak pada meluapnya air pada badan sungai dan menggenangi pemukiman jika terjadi hujan dengan intensitas tinggi dan durasi yang cukup lama.

Potensi Daerah Aliran Sungai (DAS) Manggar Besar $\pm 11.893 \mathrm{Ha}$, saat ini telah difungsikan sebagai sumber pasokan air baku PDAM kota Balikpapan, dengan kapasitas produksi 1.100 1/det. dengan pengambilan periode harian, dan kemampuan produksi pada musim kemarau adalah 160 hari tanpa hujan. Daerah Aliran Sungai (DAS) bagian Hulu dan tengah DAS merupakan kawasan hutan lindung, hutan konservasi dan perkebunan, bagian hilir merupakan daerah permukiman, pertanian, perikanan dan kawasan usaha lain. Akibat kegiatan pembangunan pada daerah Hulu DAS mengakibatkan hilangnya vegetasi, penebangan pohon di sepanjang tebing sungai dan pada daerah bantaran (riparian) memiliki pengaruh yang besar pada stabilitas tebing.

Saat ini luas DAS Manggar besar telah berkurang $19,78 \%$, menjadi \pm 9540.01 Ha. Tentunya hal ini mempengaruhi keberlanjutan ketersediaan cadangan air baku di waduk. Dimana sebagai sungai tadah hujan ketersediaan airnya sangat tergantung dari kemampuan DAS nya untuk menyimpan air. Dampak kerusakan DAS juga mempengaruhi daerah hilir DAS yaitu meningkatnya potensi banjir, masalah sedimentasi yang mempengaruhi kualitas air dan arus balik.

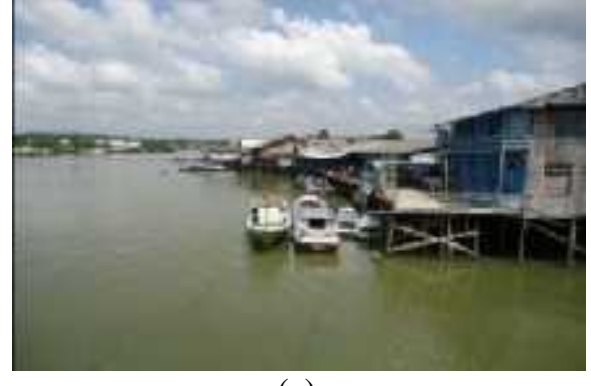

(a) 


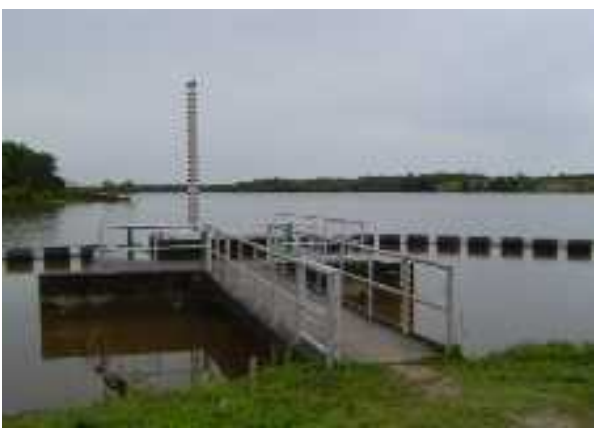

(b)

Gambar1. (a), (b) Kondisi alur Sungai Manggar Besar

Selain sungai Manggar Besar, sungai Teritip juga memiliki potensi pengembangan dalam rencana penyediaan air baku kota Balikpapan dengan luas DAS 816 Ha. Adanya aliran run off yang cukup besar dan bermuara di sungai Teritip sehingga cocok menjadi waduk alternative yang memiliki fungsi selain menampung aliran air hujan juga berfungsi sebagai pengendali banjir.

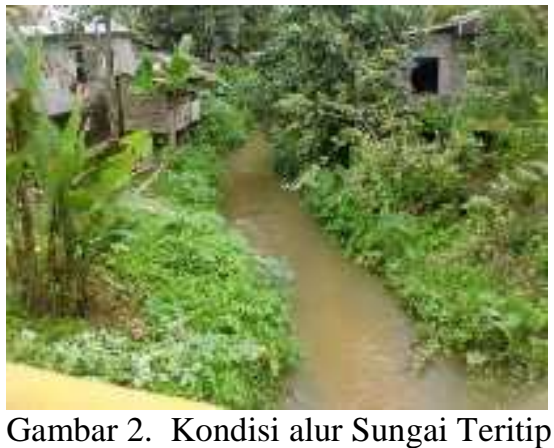

Sungai besar lainnya yang memiliki potensi sebagai sumber air baku yaitu sungai Wain dengan luas DAS 7203,18 Ha dan debit rata-rata $113.60 \mathrm{~m}^{3} /$ det. Letak sungai Wain yaitu di kecamatan Balikpapan Barat dengan luas wilayah $179.95 \mathrm{Km}^{2}$ dan kepadatan penduduk 95.806. Pemanfaatan sumber air pada sungai Wain saat ini hanya dimanfaatkan untuk melayani kebutuhan air domestik dan industri Pertamina dan kawasan perumahan pegawai pertamina.

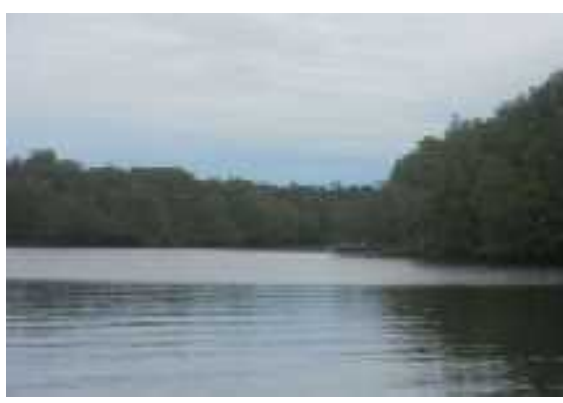

Gambar 3. Kondisi alur Sungai Wain

\section{Metoda Penelitian}

\subsection{Tujuan Penelitian}

Penelitian ini bertujuan untuk mengetahui tingkat kelayakan dari beberapa alternatif rencana penyediaan infrastruktur air baku kota Balikpapan dan aspek-aspek yang mempengaruhi tingkat kelayakannya.

\subsection{Tempat dan Waktu Penelitian}

Penelitian ini dilaksanakan di 3 lokasi waduk yang ada di wilayah kota Balikpapan yaitu : waduk sungai Manggar Besar, waduk sungai wain dan waduk sungai Teritip. Waktu pelaksanaan penelitian dilakukan selama lima bulan yaitu dimulai pada minggu ke tiga bulan Mei 2016 sampai dengan minggu ke tiga bulan November 2016.

\subsection{Rancangan Penelitian}

Metodologi yang digunakan pada penelitian ini adalah metode deskriptif yaitu studi (penelitian) yang menggambarkan keadaan nyata suatu kondisi dalam contoh kasus, dengan cara pendekatan analisis kuantitatif dengan melakukan analisis data dari hasil studi literatur, studi refrensi dari instansi terkait, pengumpulan data-data berdasarkan hasil pengamatan pada sumber data dilapangan.

Pengumpulan data penelitian ini di lakukan pada 3 (tiga) lokasi waduk di kota Balikpapan yaitu : Waduk Sungai Manggar Besar, dan lokasi rencana pembangunan Waduk baru yaitu Sungai Wain dan Sungai Teritip.

Wawancara terstruktur dengan pihakpihak terkait yaitu stakeholder yang terlibat pada tahapan Pra-konstruksi 
sehingga memberi gambaran mengenai aspek-aspek yang mempengaruhi kelayakan suatu proyek untuk menjadi dasar pengambilan keputusan pembangunan infrastruktur air baku.

\section{Hasil Penelitian}

\subsection{Proyeksi Kebutuhan Air Baku}

Permasalahan air baku di suatu perkotaan dapat dilatar belakangi oleh beberapa faktor teknis diantaranya pertumbuhan penduduk yang tidak seimbang dengan ketersediaannya, adanya perubahan iklim seperti kemarau panjang yang menyebabkan sumber-sumber air menjadi kering, serta adanya kerusakan lingkungan akibat perubahan-perubahan fungsi lahan.

Selain itu faktor lainnya yang bersifat non teknis seringkali justru menjadi polemik dan penghambat dalam pengembangan air baku pada suatu perkotaan diantaranya masalah pembebasan lahan dan kebijakankebijakan yang terkait dengan lingkungan sosial suatu masyarakat[3].

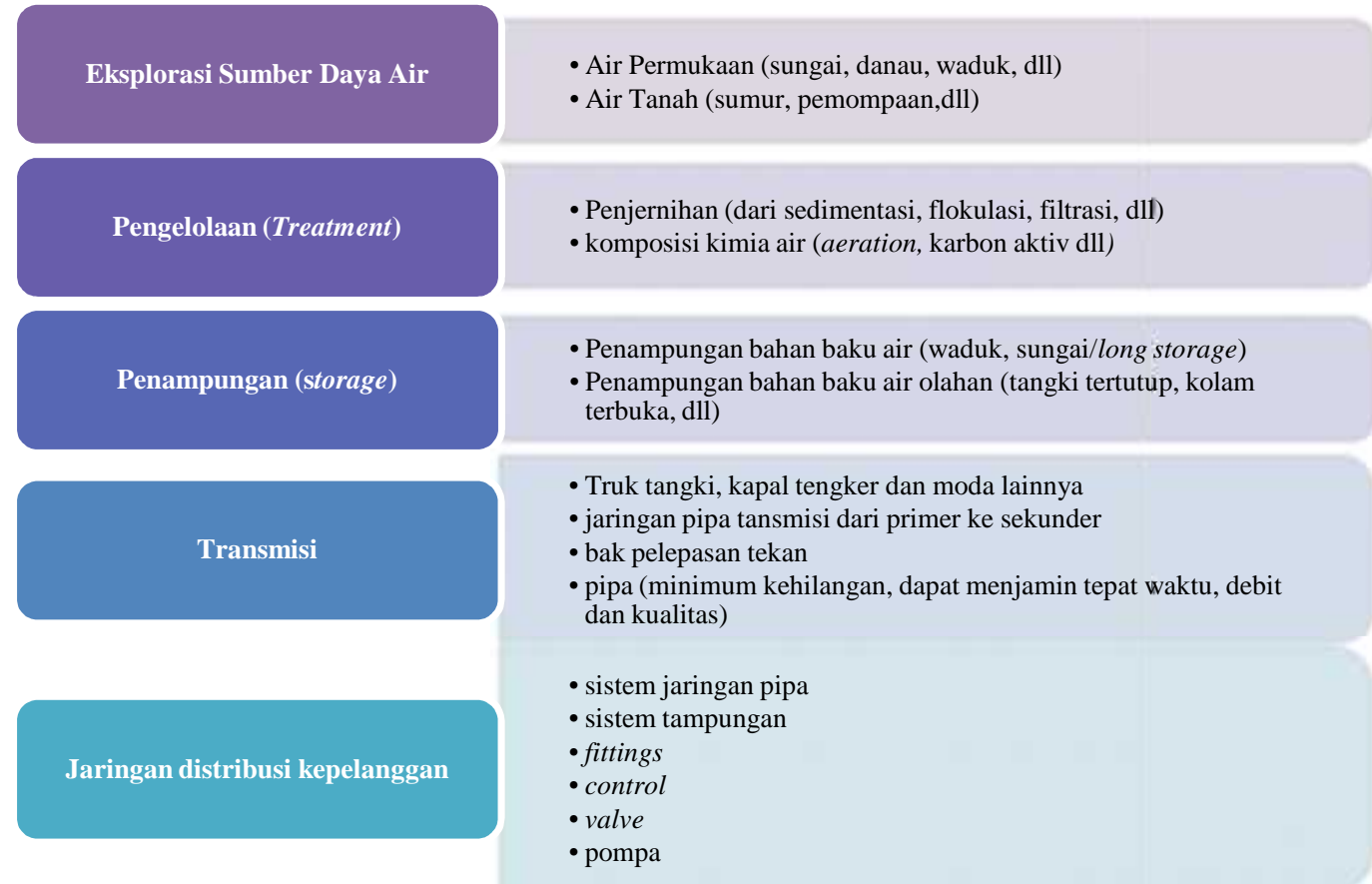

Gambar 4. Sistem Penyediaan Air Baku

Pengelolaan dan proses infrastruktur air baku untuk penyediaan sistem air bersih adalah serangkaian sistem yang terdiri dari sub-sub sistem eksplorasi sumber daya air, pengolahan (treatment) untuk memenuhi kualitas air tertentu dan meningkatkan nilai tambah air, penampungan (strorage), transmisi sampai pada jaringan distribusi kepada pelanggan[6].

Sistem penyediaan air baku kota Balikpapan di bagi dalam 5 zona yaitu:

1. Zona Manggar : sumber airnya disuplai saat ini oleh waduk
Manggar dengan total pengambilan saat ini sebesar $1.100 \mathrm{lt} / \mathrm{det}$

2. Zona Teritip : sumber airnya disuplai saat ini oleh beberapa sumur dalam dari air tanah sebesar $20 \mathrm{lt} /$ det disuplai oleh 14 sumur dalam. Kondisi sumur sudah mengalami penurunan kapasitas

3. Zona Batu Ampar : Sumber airnya disuplai saat ini oleh waduk Manggar dan beberapa sumur dalam dari air tanah 
4. Zona Kawasan Industri Kariangau : sumber airnya disuplai oleh waduk Manggar dan sumur dalam [1]

5. Zona Kampung Damai : sumber airnya disuplai oleh waduk manggar dan beberapa sumur dalam dari air tanah sebesar 89 lt/det disuplai oleh 6 sumur dalam.

Tabel 1. Proyeksi kebutuhan air baku penduduk kota Balikpapan 5 tahun (2009-2025)

\begin{tabular}{|c|c|c|c|c|c|}
\hline \multirow{2}{*}{ Uraian } & \multirow{2}{*}{$\begin{array}{l}\text { Eksisting } \\
2009\end{array}$} & \multicolumn{4}{|c|}{ Proyeksi } \\
\hline & & 2010 & 2015 & 2020 & 2025 \\
\hline \multicolumn{6}{|l|}{ Penduduk dan Coverage } \\
\hline - Jumlah penduduk (jiwa) & 613.812 & 632.226 & 657.970 & 759.441 & 876.560 \\
\hline - Jumlah pddk terlayani & 438.000 & 456.000 & 494.907 & 536.583 & 587.223 \\
\hline - Cakupan pelayanan (\%) & 71 & 72 & 76 & 80 & 85 \\
\hline \multicolumn{6}{|l|}{ Kebutuhan Air } \\
\hline - $\quad$ Rumah Tangga (SR) (l/dt) & 789 & 821 & 891 & 966 & 1.057 \\
\hline - Hidran umum (HU) (1/dt) & 5 & 3 & 3 & 2 & 2 \\
\hline $\begin{array}{l}\text { Kebutuhan air }(\mathrm{SR}+\mathrm{HU}) \\
(1 / \mathrm{dt})\end{array}$ & 794 & 824 & 894 & 968 & 1.059 \\
\hline \multirow{3}{*}{\multicolumn{6}{|c|}{$\begin{array}{ll}\text { - } & \text { Non Domestik (1/dt) } \\
\text { Kebutuhan air D dan ND } \\
\text { Kehilangan Air }\end{array}$}} \\
\hline & & & & & \\
\hline & & & & & \\
\hline - $\quad$ Proses produksi (\%) & 3 & 3 & 3 & 3 & 3 \\
\hline - $\quad$ Pipa distribusi $(\%)$ & 26 & 26 & 25 & 23 & 22 \\
\hline - $\quad$ Total kehilangan air (\%) & 29 & 29 & 28 & 26 & 25 \\
\hline \multirow{2}{*}{\multicolumn{6}{|c|}{$\begin{array}{ll}\text { - } & \text { Total kehilangan air (1/dt) } \\
\text { Kebutuhan Air }\end{array}$}} \\
\hline & & & & & \\
\hline $\begin{array}{l}\text { - Kebutuhan air baku rata-rata } \\
(1 / d t)\end{array}$ & 1.176 & 1.222 & 1.310 & 1.402 & 1.522 \\
\hline $\begin{array}{l}\text { - Kebutuhan air baku }(1.15 \mathrm{x} \\
\text { rerata) }(1 / \mathrm{dt})\end{array}$ & 1.353 & 1.405 & 1.506 & 1.613 & 1.751 \\
\hline $\begin{array}{l}\text { - Kapasitas air baku eksisting } \\
\text { (1/dt) }\end{array}$ & 1.140 & 1.140 & 1.140 & 1.140 & 1.140 \\
\hline Kapasitas tambahan (1/dt) & 213 & 265 & 366 & 473 & 611 \\
\hline
\end{tabular}

Sebagian besar zona dilayani oleh waduk Manggar yang sumber airnya berasal dari Sungai Manggar Besar, hanya pada zona teritip yang menggunakan sumber air sumur dalam. Dengan makin meningkatnya permintaan akan kebutuhan air bersih seiring meningkatnya jumlah penduduk kota maka perlu ada solusi bagi pemerintah kota dalam memecahkan permasalahan-permasalahan kelangkaan air baku terutama pada musim kemarau panjang dimana waduk Manggar sudah tidak mampu mensuplai air karena ketersediaan air yang menurun.

\subsection{Kelayakan Aspek Teknis pengadaan infrastruktur Air Baku}

Pengadaan Infrastruktur dapat dikatakan layak apabila memenuhi manfaat/benefit yang diperoleh pada masa mendatang lebih besar dari biaya (investasi) yang dikeluarkan saat ini[5]. yang dapat dipilih oleh Pemerintah Kota Balikpapan untuk menyelesaikan dan mendapatkan solusi dari permasalahan penyediaan air baku. Kelayakan suatu investasi penyediaan air baku harus mampu memenuhi kelayakan aspek teknis, kelayakan aspek legal dan kelayakan aspek finansial[7] : 
Dalam hal ini untuk memenuhikelayakan dalam penyediaan air baku perlu dianalisis manfaat/benefit yang diperoleh dari beberapa alternative
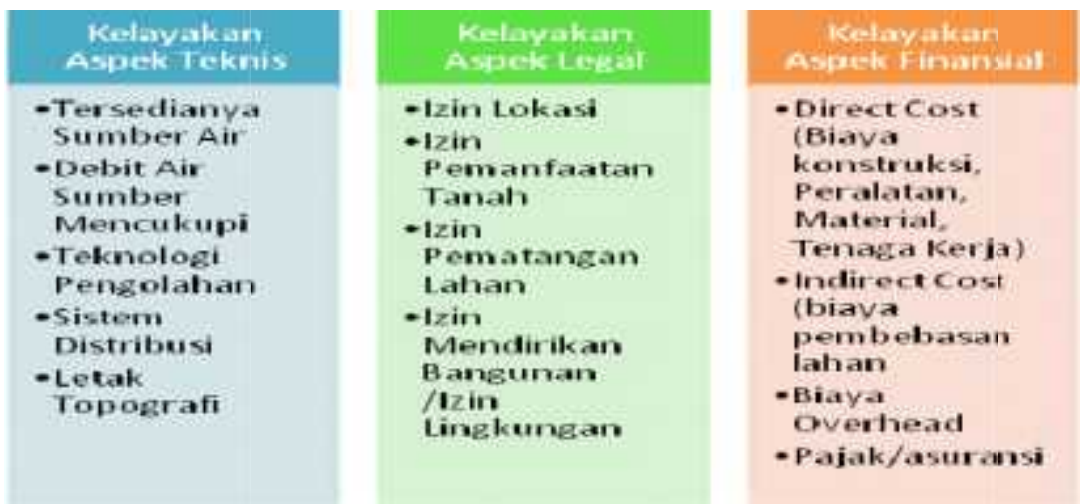

Gambar 5. Aspek-aspek Analisa Kelayakan

a. Manfaat teknis dan lingkungan

Manfaat teknis dari dibagunnya infrastruktur air baku adalah tersedianya bangunan yang dapat menampung debit air sungai yang Tabel 2.Faktor-faktor teknis dalam pemilihan alternatif air baku

\begin{tabular}{|c|c|c|c|c|}
\hline Sumber Air Baku & Debit & Teknik Pengolahan & Sistem Distribusi & $\begin{array}{l}\text { Letak } \\
\text { Topografi }\end{array}$ \\
\hline - $\quad$ Sungai Teritip & $150 \mathrm{l} / \mathrm{det}$ & Sederhana s.d rumit & $\begin{array}{l}\text { - Sistem Gravitasi } \\
\text { - pipa }\end{array}$ & $2 \%-40 \%$ \\
\hline - $\quad$ Sungai Wain Bugis & $2201 /$ det & Sederhana s.d rumit & $\begin{array}{l}\text { - Sistem Gravitasi } \\
\text { - pipa }\end{array}$ & $15 \%-40 \%$ \\
\hline $\begin{array}{ll}\text { Interkoneksi dengan } \\
\text { Kabupaten Kukar- } \\
\text { Penajam Pasir Utara }\end{array}$ & $15001 /$ det & $\begin{array}{l}\text { Sederhana s.d } \\
\text { Rumit }\end{array}$ & Sistem Pipa & $2 \%-15 \%$ \\
\hline - Pengolahan Air Laut & $\begin{array}{l}\text { Tidak } \\
\text { Terbatas }\end{array}$ & Rumit & Penguapan dan WTP & \\
\hline
\end{tabular}

b. Manfaat Sosial dan Ekonomi

Pembangunan $\begin{array}{r}\text { waduk } \\ \text { memberikan }\end{array}$ beragam
manfaat
disamping memenuhi kebutuhan pokok akan air bersih/air minum seperti untuk pengendali banjir, irigasi dan pembangkit energi listrik. Manfaat sosial dan ekonomi dapat diperoleh oleh masyarakat yaitu sebagai tempat wisata dan edukasi. Dengan banyak pengunjung dari luar yang datang ke lokasi waduk, tentunya akan mempengaruhi ekonomi masyarakat daerah disekitar yang juga akan ikut tumbuh. dapat memenuhi kebutuhan air baku kota Balikpapan Untuk memenuhi manfaat teknis, beberapa faktor yang perlu dipertimbangkan yaitu : 
kadang masih memerlukan tambahan dari anggaran belanja Pemerintah.

Biaya konstruksi merupakan biaya yang dikeluarkan untuk pembangunan fisik suatu bangunan infrastruktur. Biaya konstruksi terdiri dari direct cost dan indirect cost[4].

- Direct cost, adalah biaya-biaya yang berkaitan secara langsung dengan kegiatan pelaksanaan pekerjaan fisik pembangunan waduk baru maupun pengembangan waduk existing seperti biaya material konstruksi, biaya tenaga kerja, biaya peralatan dan lain sebagainya.

- Indirect Cost, adalah biaya-biaya yang berkaitan secara tidak langsung dengan kegiatan pelaksanaan pekerjaan fisik pembangunan waduk ataupun pengembangan waduk existing yang meliputi biaya-biaya pembebasan lahan, biaya overhead, biaya pajak, biaya asuransi dan lain sebagainya.

Selain biaya-biaya langsung yang dapat diperhitungkan pada investasi pembangunan waduk juga timbul nilai dari dampak pembangunan yang mempengaruhi pengguna maupun bukan penggunan (masyarakat sekitar), dimana nilainya tidak dapat dikuantifikasikan atau dihitung adalah termasuk biaya Intangible Cost. Itangible Cost dapat berpengaruh kepada penurunan produktivitas penggunan maupun bukan penggunan secara tidak langsung. Intangible Cost pada umumnya memiliki dampak sosial kepada masyarakat umumnya yang terkena relokasi. Selain dampak sosial, konservasi lahan dampak lingkungan juga terjadi pada kawasan yang terkena pembangunan waduk. Adanya perubahan guna lahan tidak selalu menjadi hal yang positif.

Perubahan fungsi lahan tersebut akan mempengaruhi keseimbangan alam secara keseluruhan. Adanya pembangunan waduk dengan membutuhkan lahan yang besar sebagai area genangan maka akan mempengaruhi keadaan alam sekitar, dan dampaknya akan terasa bagi masyarakat setempat.

\subsection{Kelayakan Aspek Legal}

Waduk merupakan infrastruktur milik Pemerintah, namun demikian dalam proses pembangunannya tetap harus mematuhi peraturan dan hukum yang dibuat oleh Pemerintah sendiri.

Beberapa peraturan yang harus dipenuhi antara lain[7] :

a. Izin lokasi

Izin lokasi untuk suatu bangunan dan fungsi lain, harus memenuhi persyaratan di peraturan sebagai berikut :

1) Peraturan Menteri Negara Agraria/Kepala BPN No. 2/1999 tentang Pemberian Izin Lokasi.

2) Peraturan Menteri Negara Agraria/Kepala BPN No. 3/1999 tentang Pemberian Hak Atas Tanah Negara.

3) Peraturan Menteri Negara Agraria/Kepala BPN No. 5/1999 tentang Pelaksanaan Hak Ulayat.

b. Izin Pemanfaatan Tanah (IPT) atau Izin Peruntukan Penggunaan Tanah (IPPT)

Dasar Peraturan Daerah Tentang Izin Peruntukan Penggunaan Tanah (IPPT) yang sesuai untuk lokasi prasarana olah raga dan prasarana umum.

c. Izin Pematangan Tanah/Lahan

Peraturan Daerah Tentang Peraturan Daerah tentang Retribusi Pemakaian Kekayaan Daerah dan Pematangan Tanah

d. Izin Mendirikan Bangunan (IMB) Undang-Undang No. 34 Tahun 2001 tentang Pajak dan Retribusi Daerah yang kemudian dijabarkan di masing-masing daerah menjadi Peraturan Daerah. 


\subsection{Analisis Pengambilan Keputusan}

Pengadaan Infrastruktur air baku yang terkesan sulit dan lambat dalam realisasinya karena dipengaruhi berbagai aspek diantaranya aspek teknis, aspek legal dan aspek financial yaitu keterbatasan kemampuan anggaran pemerintah, memerlukan sinkronisasi antara pengembangan hulu dan hilir, permasalahan sosial, tidak selalu layak dari segi ekonomi dan terbatasnya peran swasta dan masyarakat. Metode pengambilan keputusan dalam upaya-upaya menjawab permasalahan kelangkaan air baku kota Balikpapan perlu dirumuskan mengingat terdapat berbagai alternatif yang memiliki ketidak pastian perlu diambil oleh pemerintah kota Balikpapan. Ada 3 (tiga) alternative penyediaan air baku yang dapat dipilih yaitu : (1) membangun waduk baru, (2)pengambilan air baku interkoneksi dengan wilayah teritip dan samboja, (3) pengolahan air laut.

\section{Kesimpulan}

Penentuan alternatif sumber air baku dipengaruhi oleh beberapa faktor yaitu : tersedianya sumber air, tersedianya debit sumber yang mencukupi, teknik pengolahan, jarak sumber air terhadap konsumen, dan letak topografi

Pemilihan alternatif penyediaan infrastruktur air baku harus memenuhi kriteria kelayakan Aspek biaya dan benefit yaitu aspek tekniks dan lingkungan, aspek finansial, aspek sosial ekonomi.

\section{Saran}

Diperlukan penelitian lebih lanjut untuk menilai kelayakan aspek investasi melalui perhitungan benefit cost ratio dan present value dari alternative infrastruktur yang dipilih.
6. Daftar pustaka

[1] Anonim, 2006, Master Plan PDAM Kota Balikpapan

[2] Anonim. 2006, Master Plan Drainase Kota Balikpapan, Dinas Pekerajaan Umum Kota Balikpapan.

[3] Balai Keamanan Bendungan, Ditjen Sumber Daya Air, 2003. Pedoman Inspeksi Keamanan Bendungan. Januari 2003

[4] DR.IR.Adhi Suyanto M.Sc,dkk., 2003, Ekonomi Teknik Proyek Sumber Daya Air PT. Mediatama Saptakarya, Jakarta.

[5] Husein Umar, 2000, Studi Kelayakan dalam Usaha dan Bisnis

[6] Hudson, W.R., Haas, R., Uddin, W., 1997,Infrastructure Management

[7] Moch. Ichsan, dkk, 1998, Analisis Studi Kelayakan dan Investasi 